\title{
How to evaluate quality of life in overweight and obese women during climacterium?
}

\author{
Livia Oliveira Munhoz ${ }^{1 *}$, Isabel Cristina Esposito Sorpreso², Maria Cristina Caceres Nogueira ${ }^{3}$, Ricardo dos Santos \\ Simões ${ }^{4}$, José Maria Soares Junior ${ }^{5}$, Edmund Chada Baracat ${ }^{6}$ \\ ${ }^{1}$ Resident in Obstetrics and Gynecology, Faculty of Medicine, University of São Paulo, Brazil. \\ ${ }^{2}$ Adjunct Professor in Gynecology, Department of Obstetrics and Gynecology, Faculty of Medicine, University of São Paulo, Brazil. \\ ${ }^{3}$ Collaborating Physician in the Division of Gynecology, Department of Obstetrics and Gynecology, Faculty of Medicine, University of São Paulo, Brazil. \\ ${ }^{4}$ Assistant Physician Doctorate student in Obstetrics and Gynecology at the Faculty of Medicine, University of São Paulo, Brazil. \\ ${ }^{5}$ Associate Professor in the Division of Gynecology, Department of Obstetrics and Gynecology, Faculty of Medicine, University of São Paulo, Brazi. \\ ${ }^{6}$ Full Professor in the Division of Gynecology, Department of Obstetrics and Gynecology, Faculty of Medicine, University of São Paulo, Brazil.
}

Division of Gynecology, Department of Obstetrics and Gynecology, School of Medicine at University of São Paulo

Article received: $7 / 15 / 2014$ Approved for publication: 7/23/2014

*Correspondence: Instituto Central do Hospital das Clínicas da Faculdade de Medicina da Universidade de São Paulo, Address: Av. Dr. Enéas de Carvalho Aguiar, $255,10^{\circ}$ andar Cerqueira César, Postal Code: 05403-000 São Paulo, SP - Brazil livia.omunhoz@gmail.com http://dx.doi.org/10.1590/1806-9282.60.05.018 Conflict of interest: none

\section{SUMMARY}

Objective: identifying the instruments used to measure quality of life during menopausal transition and post-menopause in women with obesity or overweight.

Methods: a systematic search using the Embase, Pubmed and Cochrane databases, and the following key-words: menopause/climacteric, quality of life, overweight/obesity. Nineteen papers that fulfilled the including criteria were found. Results: eighteen studies using generic health questionnaires (global quality of life) were identified, six of them were specific for menopause and one specific for obesity. Eleven studies used generic questionnaires, while only eight questionnaires were specific for menopause.

Conclusion: there was no consensus in the literature about the use of quality of life questionnaires in women with overweight and obesity in climacterium, which makes de comparison and reproducibility of the results difficult. This is an alert about the need for standardization to better evaluate this specific population.

Keywords: menopause, climacteric, overweight, obesity, quality of life.

\section{INTRODUCTION}

Obesity is a multifactorial disease, epidemic in nature, which according to the World Health Organization affects over 300 million adults worldwide. Overweight individuals correspond to about one billion adults. ${ }^{1}$ The body mass index (BMI) of women seems to reach its highest values between 50 and 59 years, a period that often coincides with menopause. ${ }^{2}$

This period is characterized by body aging linked to progressive hypoestrogenism, which not only triggers health implications, but is also associated with changes in women's lives. Characteristic symptoms may be observed, including vasomotor, psychological, urogenital, sleep disturbances and sexual dysfunction, as well as difficulties in emotional and social sphere..$^{3-6}$ The quality of life in postmenopausal women is a major subject, because its results can help define therapeutic approaches and promote healthier aging for females, with improved quality of life. ${ }^{4,5,7}$

Research shows associations among obesity, menopausal symptoms and worse quality of life. ${ }^{5,8-17}$ To conduct this evaluation, various types of questionnaires are used, both generic - analyzing overall quality of life for any population - and specific questionnaires to analyze the quality of life in the transition to menopause and postmenopause. ${ }^{18-21}$

The objective of this work is to identify the instruments used to measure the quality of life of overweight and obese women in climacteric age (during the transi- 
tion to menopause and post-menopause), through a systematic review of the literature.

\section{Methods}

A systematic search was performed using the Embase, Pubmed and Cochrane databases, and the following key-words: menopause/climacteric, quality of life, overweight/ obesity. Full articles and editorials in English, Portuguese and Spanish were selected. Inclusion criteria were: full articles that used at least one questionnaire to assess quality of life or questionnaire related to climacteric symptoms, being at least part of the sample comprised of patients with overweight, obesity or metabolic syndrome who were also in transition to menopause and post-menopause. Exclusion criteria were: case reports and systematic reviews. Using these criteria were selected twenty-two articles after reading the title and abs- tract. After reading the full articles, three were excluded for the following reasons: the first examined only psychological well-being, the second used questionnaires of quality of life specific to women with breast cancer, and the third used specific questionnaires for urinary incontinence and sexual function. In the end, 19 articles were selected for this systematic review.

\section{Results}

Nineteen articles were found in the systematic literature search. The characteristics of both the articles and questionnaires used are summarized in Table 1. The studies were published between 1999 and 2013, and ten of these were dated 2009 or later. The different populations ranged from 40 to 70 years of age, $\mathrm{n}$ ranged from 30 to 161.393 women, with the majority (13) of research having $n$ of 200-1,194.

TABLE 1 Summary of articles that used questionnaires to assess quality of life in overweight or obese women in transition to menopause and post-menopause, identifying the year of publication, the instrument used, age range and/or mean population and number of participants

\begin{tabular}{|c|c|c|c|c|}
\hline Year & Author & Instruments & Age (mean) & n \\
\hline 2013 & Ashok $\mathrm{P}$ et al. ${ }^{22}$ & $\begin{array}{l}\text { World Health Organization five-item well-being index (WHO- } \\
5)\end{array}$ & $40-60$ & 60 \\
\hline 2012 & Gallon CW et al. ${ }^{33}$ & Menopause Rating Scale (MRS) & $40-65(52.8)$ & 200 \\
\hline 2011 & Imayama I et al. ${ }^{23}$ & $\begin{array}{l}\text { SF-36; Brief Symptom Inventory-18; Perceived Stress Scale; } \\
\text { Social Support Survey }\end{array}$ & $50-75(58)$ & 439 \\
\hline 2011 & Heidelberg DA et al. ${ }^{24}$ & SF-12 & $35-74$ & 983 \\
\hline 2010 & Lynch CP et al. ${ }^{25}$ & $\begin{array}{l}\text { Items taken from instruments used in the WHI trial to assess } \\
\text { emotional aspects of quality of life; SF- } 36 \text { to evaluate physical } \\
\text { aspects of quality of life }\end{array}$ & $50-79$ & 161,393 \\
\hline 2010 & Alonso AMF et al. ${ }^{9}$ & Kupperman Index & $(49.9)$ & 574 \\
\hline 2010 & Riesco E et al. ${ }^{26}$ & SF-36 & $\begin{array}{l}\text { Pre-menopausal women (49) } \\
\text { Post-menopausal women (52) }\end{array}$ & 30 \\
\hline 2009 & González FG et al. ${ }^{27}$ & EuroQol 5-D; Rosenberg Self-Esteem Scale & $(60.53)$ & 106 \\
\hline 2009 & Castelo-Branco C et al. ${ }^{34}$ & Cervantes Scale & $45-64(54.38)$ & 284 \\
\hline 2009 & Llaneza P et al. ${ }^{35}$ & Cervantes Scale & $50-65$ & 496 \\
\hline 2009 & Messier $V$ et al. ${ }^{28}$ & Medical Outcomes Study General Health Survey (MOS) & $46-70$ & 136 \\
\hline 2008 & Karelis AD et al. ${ }^{29}$ & $\begin{array}{l}\text { Medical Outcomes Study General Health Survey (MOS); } \\
\text { Perceived Stress Scale; Self- Esteem Scale; Body-Esteem } \\
\text { Scale; Scale of perceived risk for developing heart disease } \\
\text { or diabetes }\end{array}$ & $46-70$ & 137 \\
\hline 2008 & Yankura $\mathrm{DJ}{ }^{30}$ & SF-36 & $52-62$ & 580 \\
\hline 2007 & Llaneza P et al. ${ }^{36}$ & Cervantes Scale & $50-64$ & 250 \\
\hline 2007 & Lemoine $\mathrm{S}$ et al. ${ }^{31}$ & SF-36; Three-Factor Eating Questionnaire & $\begin{array}{l}\text { Pre-menopausal women 30-45(39) } \\
\text { Post-menopausal women 49-64 (56) }\end{array}$ & 40 \\
\hline 2007 & Daley A et al. ${ }^{37}$ & Women's Health Questionnaire (WHQ) & $46-55(50.5)$ & 1,194 \\
\hline 2007 & Chedraui $\mathrm{P}$ et al. ${ }^{38}$ & MENQOL & $40-70(55.9)$ & 325 \\
\hline 2006 & Mirzaiinjmabadi K et al. ${ }^{39}$ & Greene Scale & $45-60$ & 883 \\
\hline 1999 & Raikkonen K et al. ${ }^{32}$ & $\begin{array}{l}\text { SF-36; Beck Depression Inventory; Spielberg Trait Anger/ } \\
\text { Anxiety Questionnaire; Scale for distress; Interpersonal } \\
\text { Support Evaluation List (ISEL) }\end{array}$ & $45-53$ & 345 \\
\hline
\end{tabular}


Twenty-four questionnaires were identified in nineteen articles (Table 2). The instruments found were divided into generic, assessing overall quality of life in any population; specific, for quality of life in women during transition to menopause and post-menopause; and restricted, for psychosocial aspects of quality of life.

TABLE 2 List of assessment tools for quality of life used in overweight and obese women in transition to menopause and post-menopause, identifying the type of instrument, frequency of use, and year of use

\begin{tabular}{|c|c|c|c|}
\hline Instrument & Type & Frequency & Year \\
\hline $\begin{array}{l}\text { World Health Organization } \\
\text { five-item well-being index } \\
(\mathrm{WHO}-5)\end{array}$ & EPS & 1 & 2013 \\
\hline $\begin{array}{l}\text { Menopause Rating Scale } \\
\text { (MRS) }\end{array}$ & EM & 1 & 2012 \\
\hline SF-36 & G & 6 & $\begin{array}{l}\text { 2011, 2010, 2010, } \\
2008,2007,1999\end{array}$ \\
\hline Brief Symptom Inventory-18 & EPS & 1 & 2011 \\
\hline Social Support Survey & EPS & 1 & 2011 \\
\hline SF-12 & G & 1 & 2011 \\
\hline Perceived Stress Scale & EPS & 2 & 2008,2011 \\
\hline $\begin{array}{l}\text { Items taken from } \\
\text { instruments used in the } \\
\text { WHI trial }\end{array}$ & EPS & 1 & 2010 \\
\hline Kupperman Index & EM & 1 & 2010 \\
\hline EuroQol 5-D & G & 1 & 2009 \\
\hline $\begin{array}{l}\text { Rosenberg Global } \\
\text { Self-Esteem Scale }\end{array}$ & EPS & 1 & 2009 \\
\hline Cervantes Scale & EM & 3 & $2009,2009,2007$ \\
\hline $\begin{array}{l}\text { Medical Outcomes Study } \\
\text { General Health Survey } \\
(\mathrm{MOS})\end{array}$ & G & 2 & 2009,2008 \\
\hline Self- Esteem Scale & EPS & 1 & 2008 \\
\hline Body-Esteem Scale & EPS & 1 & 2008 \\
\hline $\begin{array}{l}\text { Scale of perceived risk for } \\
\text { developing heart disease or } \\
\text { diabetes }\end{array}$ & EPS & 1 & 2008 \\
\hline $\begin{array}{l}\text { Three-Factor Eating } \\
\text { Questionnaire }\end{array}$ & EPS & 1 & 2007 \\
\hline $\begin{array}{l}\text { Women's Health } \\
\text { Questionnaire (WHQ) }\end{array}$ & EM & 1 & 2007 \\
\hline MENQOL & EM & 1 & 2007 \\
\hline Greene Scale & EM & 1 & 2006 \\
\hline Beck Depression Inventory & EPS & 1 & 1999 \\
\hline $\begin{array}{l}\text { Spielberg Trait Anger/ } \\
\text { Anxiety Questionnaire }\end{array}$ & EPS & 1 & 1999 \\
\hline Scale for Distress & EPS & 1 & 1999 \\
\hline $\begin{array}{l}\text { Interpersonal Support } \\
\text { Evaluation List (ISEL) }\end{array}$ & EPS & 1 & 1999 \\
\hline
\end{tabular}

G: generic quality of life instrument; EM: specific instrument for quality of life in the transition to menopause and post-menopause; EPS: specific instrument for psychosocial aspects of quality of life.
Four different instruments were identified to assess overall quality of life. For specific analysis of quality of life related to the climacteric period, six different questionnaires were used. Most instruments found (fourteen) aimed to quantify the quality of life related to psychosocial aspects.

The SF-36 was observed more frequently, being used in six articles published from 1999 to 2011. The second most frequently found was the Cervantes Scale, seen in three articles, two published by a single group of researchers (Lhaneza et al. ${ }^{35,36}$ ). The Medical Outcome Study General Health Survey (MOS) was used in two articles, and the other questionnaires in one study only.

Six studies used more than one instrument to measure quality of life. Eight studies used specific questionnaires for menopause, while 11 used generic questionnaires, combined or not with instruments for psychosocial analysis.

\section{Discussion}

The nineteen studies obtained used twenty-four different scales. Eleven used generic questionnaires, ${ }^{22-32}$ while eight employed specific instruments to assess quality of life in women before and after menopause. ${ }^{9,33-39} \mathrm{~A}$ single article made reference to a specific questionnaire related to obesity. ${ }^{31}$

The SF-36 and Medical Outcomes Study General Health Survey (MOS) questionnaires, which are derived from the same study, were the most prevalent generic tools, being found in eight articles. ${ }^{23,25,26,28-32}$ The SF-36 was the most widely adopted, being found in six articles, ${ }^{23,25,26,30-32}$ which is consistent with the literature, since it is the most widely used generic instrument documented in over four hundred publications. ${ }^{40,41}$ However, none of these questionnaires takes into consideration important aspects such as menopausal symptoms or specific psychosocial conditions regarding this time of life, which hinders the assessment of quality of life in this population. The social psychological aspect was measured by fourteen different scales covering aspects of emotional health and the social structure in which the individual lives, which affect the quality of life. Six articles used generic instruments combined with psychosocial questionnaires, showing that the use of generic instruments may fail to take into account important aspects of quality of life in the period close to menopause. $23,25,27,29,31,32$

Ashok et al. ${ }^{22}$ used the World Health Organization five-item well-being index (WHO-5) well-being questionnaire, which assesses psychological and not physical dimensions related to menopause. ${ }^{22}$ Lynch et al. ${ }^{25}$ used the SF-36 together with a questionnaire to determine psychosocial quality of life created from instruments used in the 
Women's Health Initiative (WHI) trial. ${ }^{25}$ Therefore, the article used its own instrument, unlike those classically found in the literature, which demonstrates the lack of standardization in the literature.

Eight of the nineteen studies used specific questionnaires for menopause. ${ }^{9,33-39}$ The Cervantes Scale was the most prevalent, found in three of them. ${ }^{3436}$ The instrument was developed in Spanish, mainly for use in this population, and translated into Portuguese, despite being validated in a limited number of countries. ${ }^{42}$ In these three studies, two were conducted by the same author (Llaneza et al. ${ }^{9}$, making it difficult to generalize the results. ${ }^{35,36}$ Alonso et al. ${ }^{39}$ used the Kupperman Index, according to the data found in the literature about its widespread use, even with criticism for not addressing urogenital, social and other symptoms related to sexuality. ${ }^{9,43-45}$ Mirzaiinjmabadi et al. ${ }^{39}$ used the Greene Scale, a list of 21 items including psychological, vasomotor and somatic symptoms, which was not exactly designed as an instrument of quality of life..$^{21,39}$ The other specific questionnaires were: Menopause Rating Scale (MRS), Women's Health Questionnaire (WHQ) and Menopause-Specific Quality of Life Questionnaire (MENQOL), which have already been validated and are the main scales currently used in studies on women in transition to menopause and post-menopause. . $33,37,38,43,46,47$ In Brazil, only WHQ, MENQOL and Cervantes Scale were validated; Greene Scale has been used for many years, and MRS is being used even without validation.

Lemoine et al. ${ }^{31}$ was the only author who used a specific questionnaire for obesity, the Three-Factor Eating Questionnaire, which is related to psychological well-being. Thus, it is important to assess the need to use specific questionnaires for obesity since the population in question is also subject to the effects of obesity as a comorbidity on quality of life. ${ }^{31}$

There is no consensus as to the best type of instrument to be used to assess quality of life. Fayers et al. ${ }^{41}$ believes that both generic and specific measures have advantages and disadvantages. He recommends the use of generic and specific instruments wherever possible, in combination, to give strength to both approaches. ${ }^{41} \mathrm{On}$ the other hand, many researchers prefer to use specific questionnaires to assess a certain condition. Chedraui et al. ${ }^{38}$ states that specific instruments are required in each condition, and menopause, or climacterium, is not an exception. ${ }^{38}$ Utian ${ }^{16}$ believes that in order to evaluate the quality of life of women in transition to menopause and post-menopause, somatic symptoms such as hot flashes, night sweats, genital atrophy and urinary incontinence, and psychological symptoms such as mood swings and life circumstances, should be included; i.e., occupational, sexual, emotional and health-related factors. ${ }^{16}$ Schneider et al. ${ }^{21}$ argues that the instrument must have certain attributes or properties of measures suitable for a particular purpose. Specific questionnaires are more sensitive to change and make sense for both the physician and patient, since the items included report highly relevant domains to that particular population. ${ }^{21}$

The varied use of questionnaires can be justified by the researcher's choice for the most widely used instruments such as the SF-36 and also the preference of certain authors to use surveys created in the language and targeted to the cultural context of the study population. ${ }^{48}$ The predilection for generic tools found in the articles used in this review fails to analyze important characteristics of the study population, given the peculiarities of both the period of transition to menopause and post-menopause and obesity. Therefore, assessment of the quality of life of these women was hindered.

\section{Conclusion}

The most widely used instrument for assessing quality of life in obese women in transition to menopause and post-menopause was the generic SF-36 questionnaire. The Cervantes Scale was the specific instrument most used. There was no consensus regarding the use of the instruments, which is an obstacle for comparison and reproducibility of results. The current study is a warning to researchers that there is a need for a standard instrument to assess this growing population.

\section{Resumo}

Como aferir qualidade de vida de mulheres com sobrepeso e obesidade no climatério?

Objetivo: identificar os instrumentos utilizados para aferir a qualidade de vida de mulheres com sobrepeso e obesidade no climatério (transição para menopausa e pós-menopausa).

Métodos: busca sistemática nas bases de dados Embase, Pubmed e Cochrane com os descritores: menopause/climacteric, quality of life, overweight/obesity. Foram incluídos 19 artigos que preencheram os critérios de inclusão.

Resultados: foram identificados 18 questionários genéricos (qualidade de vida global), 6 específicos para menopausa e 1 específico para obesidade. Onze estudos utilizaram instrumentos genéricos, enquanto 8 utilizaram específicos para menopausa. 
Conclusão: não houve consenso na literatura quanto ao uso de instrumentos de qualidade de vida em mulheres com sobrepeso e obesidade no climatério, o que dificulta a comparação e a reprodutibilidade dos resultados. Este é um alerta quanto à necessidade de padronização para melhor avaliar essa população específica.

Palavras-chave: menopausa; climatério; sobrepeso; obesidade; qualidade de vida.

\section{References}

1. De Lorenzi DRS, Basso E, Fagundes PO, Saciloto B. Prevalência de sobrepeso e obesidade no climatério. Rev Bras Ginecol Obstet. 2005;27(8):479-84.

2. Teede HJ, Lombard C, Deeks AA. Obesity, metabolic complications and the menopause: an opportunity for prevention. Climacteric. 2010 Jun;13(3):203-9.

3. Davis SR, Castelo-Branco C, Chedraui P, Lumsden MA, Nappi RE, Shah D, et al. Understanding weight gain at menopause. Climacteric. 2012 Oct;15(5):419-29.

4. Conde DM, Pinto-Neto AM, Santos-Sá D, Costa-Paiva L, Martinez EZ. Factors associated with quality of life in a cohort of postmenopausal women. Gynecological endocrinology. 2006 Aug;22(8):441-6.

5. Lorenzi DRS, Baracat EC, Saciloto B, Padilha IJ. Fatores associados à qualidade de vida após menopausa. Rev Assoc Med Bras. 2006;52(5):312-7.

6. Lorenzi DRS, Catan LB, Cusin T, Felini R, Bassani F, Arpini AC. Caracterização da qualidade de vida segundo o estado menopausal entre mulheres da Região Sul do Brasil. Rev Bras Saúde Matern Infant. 2009;9(4):459-66.

7. Filho EAS, Costa AM. Avaliação da qualidade de vida de mulheres no climatério atendidas em hospital-escola na cidade do Recife, Brasil. Rev Bras Ginecol Obstet. 2008;30(3):113-20.

8. Coakley EH, Kawachi I, Manson JE, Speizer FE, Willet WC, Colditz GA. Lower levels of physical functioning are associated with higher body weight among middle-aged and older women. International journal of obesity and related metabolic disorders. 1998 Oct;22(10):958-65.

9. Fernández-Alonso AM, Cuadros JL, Chedraui P, Mendoza M, Cuadros AM, Pérez-López FR. Obesity is related to increased menopausal symptoms among Spanish women. Menopause international. 2010 Sep;16(3):105-10.

10. López-García E, Banegas JRB, Gutiérrez-Fisac JL, Pérez-Regadera AG, Gañán LD, Rodríguez-Artalejo F. Relation between body weight and health-related quality of life among the elderly in Spain. International journal of obesity and related metabolic disorders. 2003 Jun;27(6):701-9.

11. Myint PK, Welch AA, Luben RN, Wainwright NWJ, Surtees PG, Bingham SA, et al. Obesity indices and self-reported functional health in men and women in the EPIC-Norfolk. Obesity. 2006 May;14(5):884-93.

12. Yan LL, Daviglus ML, Liu K, Pirzada A, Garside DB, Schiffer L, et al. BMI and health-related quality of life in adults 65 years and older. Obesity research. 2004 Jan;12(1):69-76.

13. Rivenes AC, Harvey SB, Mykletun A. The relationship between abdominal fat, obesity, and common mental disorders: results from the HUNT study. Journal of psychosomatic research. Elsevier Inc. 2009 Apr;66(4):269-75.

14. Sorpreso ICE, Vieira LHL, Haidar MA, Nunes MG, Baracat EC, Júnior JMS. Multidisciplinary approach during menopausal transition and post-menopause in Brazilian women. Clin Exp Obstet Gynecol. 2010;37(4):283-6.

15. Sorpreso ICE, Vieira LHL, Calió CC, Abi Haidar M, Baracat EC, Soares JM. Health education intervention in early and late postmenopausal Brazilian women. Climacteric. 2012;15(6):573-80.

16. Utian WH. Psychosocial and socioeconomic burden of vasomotor symptoms in menopause: A comprehensive review. Health and quality of life outcomes. 2005;3(47):1-10.

17. Calio CL, Sorpreso ICE, Haidar MA, Maciel GA, Baracat EC, Soares JMJ. Physiotherapeutic approach in early and late post-menopausal Brazilian women. Gynecol Endocrinol. 2013;29(7):670-3.

18. Sorpreso ICE. Atenção Integral à Saúde da Mulher na Transição para Menopausa e Pós-menopausa. 2010.
19. Silveira MF, Almeida JC, Freire SR, Haikal DS, Martins AEBL. Propriedades psicométricas do instrumento de avaliação da qualidade de vida: 12-item health survey (SF-12). Ciência e Saúde Coletiva. 2013;18(7):1923-31.

20. Neto AMP, Conde DM. Qualidade de vida. Rev Bras Ginecol Obstet. 2008;30(11):535-6.

21. Schneider HPG, Maclennan H, Feeny D. Assessment of health-related quality of life in menopause and aging. Climacteric. 2008 Apr;11(2):93-107.

22. Ashok P, Apte G, Wagh G, Joshi A. Psychological Well-Being \& obesity in Peri and Post-menopausal women. National Journal of Physiology, Pharmacy and Pharmacology. 2013;3(1):97-101.

23. Imayama I, Alfano CM, Kong A, Foster-Schubert KE, Bain CE, Xiao L, et al. Dietary weight loss and exercise interventions effects on quality of life in overweight/obese postmenopausal women: a randomized controlled trial. International journal of behavioral nutrition and physical activity. BioMed Central Ltd. 2011 Jan;8(1):118.

24. Heidelberg DA, Holle R, Lacruz ME, Ladwig K-H, Von Lengerke T. Do diabetes and depressed mood affect associations between obesity and quality of life in post-menopause? Results of the KORA-F3 Augsburg population study. Health and quality of life outcomes. BioMed Central Ltd; 2011 Jan;9(1):97.

25. Lynch CP, McTigue KM, Bost JE, Tinker LF, Vitolins M, Adams-Campbell $\mathrm{L}$, et al. Excess weight and physical health-related quality of life in postmenopausal women of diverse racial/ethnic backgrounds. Journal of women's health. 2010 Aug;19(8):1449-58.

26. Riesco E, Tessier S, Pérusse F, Turgeon S, Tremblay A, Weisnagel J, et al. Impact of walking on eating behaviors and quality of life of premenopausal and early postmenopausal obese women. Menopause. 2010;17(3):529-38.

27. González FG, García JCF, Rubio AB, Galera RA, Macagno LE, Abella CP, et al. An ambulatory physical exercise program improves in the short term weight and quality of life of obese post-menopausal women. Medicina clínica. 2009 Oct 17;133(14):533-8.

28. Messier V, Karelis AD, Lavoie M-E, Brochu M, Faraj M, Strychar I, et al. Metabolic profile and quality of life in class I sarcopenic overweight and obese postmenopausal women: a MONET study. Appl. Physiol. Nutr. Metab. 2009 Feb;34:18-24.

29. Karelis AD, Fontaine J, Messier V, Messier L, Blanchard C, Rabasa-Lhoret $\mathrm{R}$, et al. Psychosocial correlates of cardiorespiratory fitness and muscle strength in overweight and obese post-menopausal women: a MONET study. Journal of sports sciences. 2008 Jul;26(9):935-40.

30. Yankura DJ, Conroy MB, Hess R, Pettee KK, Kuller LH, Kriska AM. Weight regain and health-related quality of life in postmenopausal women. Obesity. 2008 Oct;16(10):2259-65.

31. Lemoine S, Rossell N, Drapeau V, Poulain M, Garnier S, Sanguignol F, et al. Effect of weight reduction on quality of life and eating behaviors in obese women. Menopause. 2007;14(3):432-40.

32. Räikkönen K, Matthews KA, Kuller LH. Anthropometric and psychosocial determinants of visceral obesity in healthy postmenopausal women. International Journal of Obesity. 1999 Aug;23:775-82.

33. Gallon CW, Wender MCO. Estado nutricional e qualidade de vida da mulher climatérica. Rev Bras Ginecol Obstet. 2012;34(4):175-83.

34. Castelo-Branco C, Palacios S, Ferrer-Barriendos J, Cancelo MJ, Quereda F, Alberich X. Impact of anthropometric parameters on quality of life during menopause. Fertility and sterility. 2009 Dec;92(6):1947-52.

35. Llaneza P, González C, Fernandez-Iñarrea J, Alonso A, Arnott I, FerrerBarriendos J. Insulin resistence and health-related quality of life in postmenopausal women. Fertility and sterility. 2009 Apr;91(4 Suppl):1370-3.

36. Llaneza P, Iñarrea J, Gonzalez C, Alonso A, Arnott I, Ferrer-Barriendos J. Differences in health related quality of life in a sample of Spanish menopausal women with and without obesity. Maturitas. 2007 Dec;58:387-94.

37. Daley A, Macarthur C, Stokes-Lampard H, McManus R, Wilson S, Mutrie N. Exercise participation, body mass index, and health-related quality of life in women of menopausal age. British journal of general practice. 2007 Feb;57:130-5.

38. Chedraui P, Hidalgo L, Chavez D, Morocho N, Alvarado M, Huc A. Quality of life among postmenopausal Ecuadorian women participating in a metabolic syndrome screening program. Maturitas. 2007 Jan 20;56(1):45-53.

39. Mirzaiinjmabadi K, Anderson D, Barnes M. The relationship between exercise, Body Mass Index and menopausal symptoms in midlife Australian women. International journal of nursing practice. $2006 \mathrm{Feb} ; 12(1): 28-34$. 
40. Ware JE, Gandek B. Overview of the SF-36 Health Survey and the International Quality of Life Assessment (IQOLA) Project. Journal of clinical epidemiology. 1998 Nov;51(11):903-12.

41. Fayers P, Hays R. Assessing Quality of Life in Clinical Trials. $2^{\text {nd }}$ ed. United Kigdon: Oxford University Press; 2005. p. 3-8.

42. Lima JEM, Palacios S, Wender MCO. Quality of life in menopausal women: a Brazilian Portuguese version of the Cervantes Scale. TheScientificWorldJournal. 2012 Jan;2012:5 pages.

43. Filho CRS, Baracat EC, Conterno LO, Haidar MA, Ferraz MB. Climacteric symptoms and quality of life: validity of women's health questionnaire. Rev Saúde Pública. 2005;39(3):333-9.

44. Schneider HP, Heinemann LA, Rosemeier HP, Potthoff P BH. The Menopause Rating Scale (MRS): comparison with Kupperman index and quality-of-life scale SF-36. Climacteric. 2000;3(1):50-8.
45. Zöllner Y, Kay S, Abetz L. La qualité de vie sexuelle des européennes. Gyn Info. 2001;51:9-11.

46. Heinemann LAJ, Potthoff P, Schneider HPG. International versions of the Menopause Rating Scale (MRS). Health and quality of life outcomes. 2003 Jan;01:28 AM.

47. Lewis JE, Hilditch JR, Wong CJ. Further psychometric property development of the Menopause-Specific Quality of Life questionnaire and development of a modified version, MENQOL-Intervention questionnaire.Maturitas. 2005;50:209-21.

48. Ciconelli RM, Ferraz MB, Santos W, Meinão I, Quaresma MR. Tradução para a língua portuguesa e validação do questionário genérico de avaliação de qualidade de vida SF-36 (Brasil SF-36). Rev Bras Reumatol. 1999;39(3):143-50. 